\title{
Infections in Hematology Patients
}

\author{
Ola Blennow and Per Ljungman
}

\section{Introduction}

In hematology patients, the immunosuppression caused by the hematologic disease and its treatment usually predicts both the severity and type of infections. Neutropenia predisposes to severe bacterial infections and, if prolonged, for fungal infections, while an impaired T-cell function increases the risk for fungal and viral infections. Besides knowledge about the patients' immune status, the local resistance pattern, such as the frequencies of extended spectrum betalactamase (ESBL)-producing Enterobacteriaceae and methillicin-resistant Staphylococcus aureus (MRSA), is important when deciding on empirical antimicrobial therapies. An important diagnostic principle in immunosuppressed patients is to "go for the bug" at the place of infection using invasive procedures, most often bronchoalveolar lavage (BAL) and biopsies.

\section{Prevention of Infections}

Prevention of infection in hematology patients consists of antimicrobial prophylaxis, prevention of exposure to infectious agents, and immune prophylaxis (vaccination; immune globulin).

Most studies of antibacterial prophylaxis have been performed with fluoroquinolones. Although the risk for neutropenic fever can be reduced, the effects on outcome have been

O. Blennow

Department of Infectious Diseases, Karolinska University

Hospital, Stockholm, Sweden

P. Ljungman $(\bowtie)$

Department of Cellular Therapy and Allogeneic Stem Cell

Transplantation, Karolinska University Hospital,

Stockholm, Sweden

Division of Hematology, Department of Medicine Huddinge,

Karolinska Institutet, Stockholm, Sweden

e-mail: Per.Ljungman@ki.se variable, and its use is controversial due to the increased rates of resistance. If antibacterial prophylaxis is to be used, it should be reserved only to high-risk patients.

Antifungal and antiviral prophylaxis regimens are discussed in sections dealing with the specific pathogens further on in this chapter. Other preventive measures are described in Table 38.1.

\section{Neutropenic Fever}

A. Epidemiology:

1. Neutropenic fever is usually defined as a single temperature measurement of $\geq 38.3^{\circ} \mathrm{C}\left(101^{\circ} \mathrm{F}\right)$ or a temperature of $\geq 38.0^{\circ} \mathrm{C}\left(100.4{ }^{\circ} \mathrm{F}\right)$ sustained over a 1-h period in a patient with ANC $<500$ cells $/ \mu \mathrm{L}$.

2. It is very common in patients with hematologic malignancies and occurs in more than $80 \%$ of patients with chemotherapy-associated neutropenia.

3. In approximately $50 \%$ of episodes, no diagnosis can be established (i.e., fever of unknown origin, FUO), whereas clinically documented infections and microbiological documented infections are diagnosed in around $25 \%$ of episodes each.

4. Bloodstream infections constitute the vast majority of microbiological documented infections. The epidemiology of bloodstream infections differs between centers, but generally there is a slight dominance of Gram-negative enteric bacteria (such as $E$. coli, K. pneumoniae, P. aeruginosa) over Grampositive pathogens (such as coagulase-negative staphylococci, viridans streptococci, E. faecium). Antimicrobial resistance is rapidly increasing among both Gram-negative and Gram-positive isolates, most importantly extended ESBL production in Enterobacteriaceae.

5. The all-over mortality is low, around $5 \%$, due to low mortality in patients with FUO. In patients with documented infections, the reported mortality 
Table 38.1 Prevention of infection in hematology patients

\begin{tabular}{|c|c|c|}
\hline Measure & Patient group & Data source/study quality \\
\hline $\begin{array}{l}\text { Isolation procedures } \\
\text { including hygienic } \\
\text { measures }\end{array}$ & $\begin{array}{l}\text { HSCT } \\
\text { patients and } \\
\text { other patients }\end{array}$ & $\begin{array}{l}\text { Epidemiological data }+ \\
\text { knowledge about } \\
\text { transmission routes }\end{array}$ \\
\hline Food safety & $\begin{array}{l}\text { HSCT and } \\
\text { other patients }\end{array}$ & $\begin{array}{l}\text { Good rationale for specific } \\
\text { pathogens (listeria, } \\
\text { salmonella). Otherwise } \\
\text { unclear effects on the } \\
\text { microbiome }\end{array}$ \\
\hline Pets & $\begin{array}{l}\text { HSCT and } \\
\text { other patients }\end{array}$ & $\begin{array}{l}\text { Good rationale, but } \\
\text { limited data }\end{array}$ \\
\hline Water safety & $\begin{array}{l}\text { HSCT and } \\
\text { other patients }\end{array}$ & $\begin{array}{l}\text { Good rationale, but } \\
\text { limited data (exception } \\
\text { legionella and HAV) }\end{array}$ \\
\hline Safe sex & $\begin{array}{l}\text { HSCT and } \\
\text { other patients }\end{array}$ & $\begin{array}{l}\text { Some rationale (HSV) but } \\
\text { no specific data }\end{array}$ \\
\hline $\begin{array}{l}\text { Antibacterial } \\
\text { prophylaxis }\end{array}$ & $\begin{array}{l}\text { HSCT and } \\
\text { other patients }\end{array}$ & $\begin{array}{l}\text { Several studies of mixed } \\
\text { quality }\end{array}$ \\
\hline $\begin{array}{l}\text { Antifungal } \\
\text { prophylaxis }\end{array}$ & $\begin{array}{l}\text { HSCT } \\
\text { patients, } \\
\text { AML/MDS }\end{array}$ & Randomized studies \\
\hline \multirow[t]{2}{*}{ Antiviral prophylaxis } & $\begin{array}{l}\text { HSCT } \\
\text { patients }\end{array}$ & $\begin{array}{l}\text { Randomized studies } \\
\text { against some viruses }\end{array}$ \\
\hline & Other patients & $\begin{array}{l}\text { Old studies of mixed } \\
\text { quality }\end{array}$ \\
\hline \multirow[t]{2}{*}{$\begin{array}{l}\text { Immunoglobulin } \\
\text { prophylaxis }\end{array}$} & $\begin{array}{l}\text { HSCT } \\
\text { patients }\end{array}$ & $\begin{array}{l}\text { Old studies of mixed } \\
\text { quality }\end{array}$ \\
\hline & Other patients & $\begin{array}{l}\text { Old studies of mixed } \\
\text { quality }\end{array}$ \\
\hline \multirow[t]{3}{*}{ Vaccination } & \multirow[t]{2}{*}{$\begin{array}{l}\text { HSCT } \\
\text { patients }\end{array}$} & $\begin{array}{l}\text { Randomized studies of } \\
\text { pneumococcal } \\
\text { vaccination. Studies of } \\
\text { mixed quality of influenza } \\
\text { vaccination }\end{array}$ \\
\hline & & $\begin{array}{l}\text { Studies of mixed quality } \\
\text { of vaccination against } \\
\text { other pathogens }\end{array}$ \\
\hline & Other patients & $\begin{array}{l}\text { Few controlled studies. } \\
\text { Uncontrolled studies of } \\
\text { mixed quality }\end{array}$ \\
\hline
\end{tabular}

HSCT allogeneic hematopoietic stem cell transplantation

rates are considerably higher: around $20 \%$ in patients with lung infiltrates, $35 \%$ in severe sepsis, and $50 \%$ in patients with septic shock [1].

B. Diagnostics:

1. A careful clinical examination should be performed daily to identify possible infection focuses and detect clinical deterioration. Focuses that are easily overlooked include dental infections and perianal infections.

2. Blood cultures should be taken through the central catheter and peripherally simultaneously, making it possible to identify catheter-related bloodstream infections (see section "CRBSI"). The total blood volume should be at least $40 \mathrm{ml}$ (i.e., four bottles) to reach an acceptable sensitivity.
3. Other cultures depend on the clinical signs of infection. Possible specimens include sputum, urine, skin, and stool samples (for Clostridium difficile).

4. PCR for respiratory viruses should be performed in severely immunocompromised patients with respiratory symptoms especially in influenza season. PCR for other viruses is usually not part of the initial workup.

5. In patients with respiratory symptoms, a thoracic CT scan should be performed. Chest X-ray is not meaningful in neutropenic patient because of low sensitivity and specificity (see also section "Pneumonia").

6. BAL should be performed if the CT scan shows lung infiltrates (Table 38.2 and section "Pneumonia").

7. New skin lesions/nodules should be biopsied and sent for microscopy and cultures, and fungal PCR should be considered.

C. Antimicrobial therapy:

1. Empirical therapy:

(a) Neutropenic fever is a potentially life-threatening infection and treatment must always be initiated promptly. Infections with Gram-negative bacteria have been associated with high mortality, and the empirical therapy must therefore always include a broad Gram-negative coverage, including Pseudomonas species. Firsthand treatment options are presented in Table $38.2[3,4]$.

(b) Vancomycin should not be added routinely to the empirical treatment because studies have clearly shown that this has no impact on mortality.

(c) Oral antimicrobial treatment may be given from the start in selected low-risk patients (Table 38.2) [5].

2. Targeted therapy:

(a) Empirical therapy can be de-escalated to targeted therapy in microbiological documented infections, but not until the patient becomes afebrile. In neutropenic patients, fever is usually the only sign of a new infection and can be missed if antimicrobial coverage is narrowed down to a targeted treatment in a persistently febrile neutropenic patient [2].

3. Duration of therapy:

(a) Patients with FUO and still neutropenic: Until $48 \mathrm{~h}$ without fever.

(b) Patients with FUO and non-neutropenic: Until resolution of fever.

(c) Patients with microbiological and clinically documented infections: Same as for FUO, with the exception that the total duration of therapy should not be shorter than the normal treatment duration in non-neutropenic patients with the same diagnosis. 
Table 38.2 Empirical antimicrobial treatment of neutropenic fever [2]

\begin{tabular}{|c|c|c|}
\hline Patient characteristics & Empirical firsthand treatment & Comment \\
\hline $\begin{array}{l}\text { No clinical focus, stable patient, no risk } \\
\text { factor for resistant pathogen }{ }^{\mathrm{a}}, \text { MASCC } \\
\text { score } \geq 21^{\mathrm{b}}\end{array}$ & $\begin{array}{l}\text { Consider outpatient treatment with } \\
\text { ciprofloxacin }+ \text { amoxicillin/clavulanate }\end{array}$ & $\begin{array}{l}\text { Usually not applied to patients with, or } \\
\text { anticipated, profound neutropenia for more } \\
\text { than } 7 \text { days }\end{array}$ \\
\hline $\begin{array}{l}\text { No clinical focus, stable patient, no risk } \\
\text { factor for resistant pathogen }{ }^{\mathrm{a}} \text {, MASCC } \\
\text { score }<21\end{array}$ & $\begin{array}{l}\text { Piperacillin/tazobactam, cefepime, } \\
\text { ceftazidime }\end{array}$ & \\
\hline MRSA colonization & $\begin{array}{l}\text { Vancomycin should be added to the empirical } \\
\text { treatment }\end{array}$ & \\
\hline $\begin{array}{l}\text { ESBL colonization (not } \\
\text { carbapenem-resistant) }\end{array}$ & Imipenem/cilastatin, meropenem & \\
\hline $\begin{array}{l}\text { ESBL (carbapenem-resistant) or multidrug- } \\
\text { resistant Pseudomonas colonization }\end{array}$ & $\begin{array}{l}\text { Often combination treatment including } \\
\text { colistin }\end{array}$ & Consider susceptibility data \\
\hline Respiratory symptoms/focus & Piperacillin/tazobactam, cefepime & $\begin{array}{l}\text { Avoid ceftazidime due to less activity against } \\
\text { viridans streptococci }\end{array}$ \\
\hline Abdominal symptoms/focus & $\begin{array}{l}\text { Piperacillin/tazobactam, imipenem/cilastatin, } \\
\text { meropenem }\end{array}$ & $\begin{array}{l}\text { Avoid single treatment with cefepime and } \\
\text { ceftazidime due to less anaerobic activity }\end{array}$ \\
\hline $\begin{array}{l}\text { Cellulitis (not associated with a central } \\
\text { catheter) }\end{array}$ & Piperacillin/tazobactam, cefepime & $\begin{array}{l}\text { Avoid ceftazidime due to less Gram-positive } \\
\text { activity }\end{array}$ \\
\hline Cellulitis around a central catheter & $\begin{array}{l}\text { Vancomycin should be added to the empirical } \\
\text { treatment }\end{array}$ & \\
\hline Tunnel infection, port abscesses & $\begin{array}{l}\text { Vancomycin should be added to the empirical } \\
\text { treatment }\end{array}$ & Remove central catheter \\
\hline \multirow[t]{3}{*}{ Severe sepsis/septic shock } & Imipenem/cilastatin or meropenem & \\
\hline & $\begin{array}{l}\text { Consider addition of amikacin and } \\
\text { vancomycin }\end{array}$ & \\
\hline & $\begin{array}{l}\text { Add empiric antifungal treatment with an } \\
\text { echinocandin if not on adequate antifungal } \\
\text { prophylaxis }\end{array}$ & \\
\hline
\end{tabular}

MRSA methillicin-resistant Staphylococcus aureus, ESBL extended spectrum beta-lactamase

ancluding prior colonization or infection with resistant pathogens, nosocomial infection, and prolonged hospital stay

${ }^{\mathrm{b}}$ The Multinational Association for Supportive Care in Cancer (MASCC) risk index score: burden of febrile neutropenia (no or mild $=5$, moderate $=3$, severe $=0$ ), systolic blood pressure $>90 \mathrm{mmHg}(5)$, no chronic obstructive pulmonary disease (4), solid tumor or hematologic malignancy with no previous fungal infection (4), no dehydration requiring iv fluid (3), outpatient status (3), age <60 years (2). Maximum = 26.

D. Neutropenic fever despite $72 \mathrm{~h}$ of treatment with broadspectrum antibiotics:

1. A management algorithm is presented in Fig. 38.1.

2. If the new diagnostic workup is negative and the patient is stable, i.e., has not deteriorated, usually no change in therapy is necessary.

3. If the neutropenic fever continues, a new cycle of diagnostic workup is initiated.

4. Addition of empiric vancomycin to a stable patient has not been shown to decrease mortality and duration of fever and should be avoided.

5. If the patient deteriorates, the antimicrobial therapy must be changed to include an even broader coverage. A carbapenem (meropenem or imipenem/ cilastatin) should be prescribed if not already given. Empirical antifungal therapy should be initiated (see section "Empirical Antifungal Therapy"), and addition of amikacin and/or vancomycin considered.

\section{Pneumonia}

A. Epidemiology:

(a) Respiratory symptoms and/or a new lung infiltrate are frequent in patients with hematologic diseases. In patients receiving treatment for acute leukemia, up to $30 \%$ may be affected with an associated mortality of over $20 \%$ [6].

(b) The etiology often depends on the underlying immunosuppression (Table 38.3). In many cases, no etiology can be established.

(c) Noninfectious reasons for a new infiltrate should be considered and include alveolar bleeding, heart failure, infiltration of the hematologic malignancy, organizing pneumonia, immune reconstitution syndrome, and damage from chemotherapy or radiation.

B. Diagnostics:

(a) The clinical presentation is usually fever and/or respiratory symptoms such as cough, dyspnea, hemoptysis, and/or impaired oxygenation. 
Table 38.3 Etiology of pneumonia

\begin{tabular}{|c|c|c|c|}
\hline Patient characteristics & Bacteria & Virus & Fungus \\
\hline $\begin{array}{l}\text { Moderate } \\
\text { immunosuppression }\end{array}$ & $\begin{array}{l}\text { Streptococcus pneumoniae, Haemophilus influenzae, } \\
\text { Staphylococcus aureus, Gram-negative enteric bacteria }\end{array}$ & Unusual & Pneumocystis pneumonia - low risk \\
\hline \multirow[t]{4}{*}{ T-cell suppression } & As above + & $\begin{array}{l}\text { Respiratory } \\
\text { virus }^{\text {b }}\end{array}$ & $\begin{array}{l}\text { Pneumocystis pneumonia - high } \\
\text { risk (if no prophylaxis) }\end{array}$ \\
\hline & \multirow[t]{3}{*}{ Mycobacterium tuberculosis } & CMV & Invasive aspergillosis \\
\hline & & \multirow[t]{2}{*}{ Adenovirus } & Mucormycosis \\
\hline & & & Other mold infections \\
\hline \multirow{6}{*}{$\begin{array}{l}\text { Prolonged neutropenia } \\
\text { (typically }>10 \text { days) }\end{array}$} & As above + & \multirow[t]{6}{*}{ Unusual } & \multirow{3}{*}{$\begin{array}{l}\text { Pneumocystis pneumonia - low to } \\
\text { moderate risk (if no prophylaxis) }\end{array}$} \\
\hline & Pseudomonas species & & \\
\hline & Nocardia species & & \\
\hline & Actinomyces species & & Invasive aspergillosis \\
\hline & Stenotrophomonas maltophilia & & Mucormycosis \\
\hline & Mycobacterium tuberculosis & & Other mold infections \\
\hline
\end{tabular}

$C M V$ cytomegalovirus

aNeutropenia $<10$ days, no treatment with high-dose glucocorticoids, no T-cell-directed therapy

${ }^{b}$ Depending on epidemiology. Includes influenza, parainfluenza $1-3$, respiratory syncytial virus (RSV), enterovirus, coronavirus, rhinovirus, human metapneumovirus

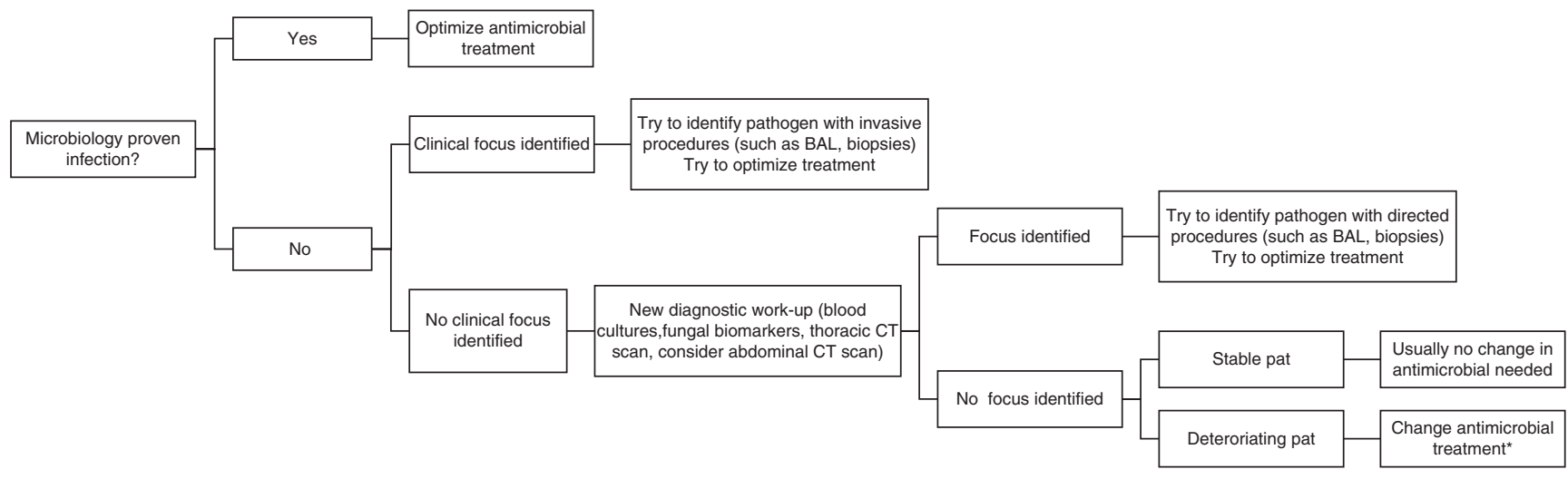

Fig. 38.1 Algorithm for management of prolonged neutropenic fever despite broad-spectrum antibiotics. * Change antibiotics to a carbapenem (meropenem or imipenem/cilastatin) if not already given. If receiv- ing carbapenem consider adding amikacin, vancomycin, and an antifungal agent (see section "Empirical Antifungal Therapy") (b) Findings on physical examination include tachypnea, impaired oxygenation, and lung crepitations.

(c) A thoracic CT scan should be performed early in patients with acute leukemia or T-cell suppression experiencing respiratory symptoms. Early detection of lung infiltrates indicating invasive mold disease or Pneumocystis jirovecii pneumonia (PCP), leading to early institution of antimicrobial treatment, has been shown to result in improved survival. Conventional chest X-ray has limited value in patients with hematologic diseases, especially when neutropenic, because of low sensitivity and specificity as compared to CT [6].

(d) The extent of microbiology sampling depends on the severity of the pneumonia and grade of immunosuppression (Tables 38.3 and 38.4). (e) BAL is often required for establishing a microbiological diagnose and should be considered early in patients with acute leukemia or T-cell suppression with lung infiltrates (Tables 38.3 and 38.4). BAL should always be performed, unless contraindicated, if no response to initial empiric antimicrobial treatment.

(f) Coagulase-negative staphylococci, enterococci, and Candida species are generally not etiologically relevant for lung infiltrates even if found in BAL culture.

C. Treatment:

(a) Empirical treatment:

1. In neutropenic patients and/or in nosocomial pneumonia, empirical treatment should include adequate Pseudomonas coverage besides cover- 
Table 38.4 Diagnostic tests in pneumonia and targeted treatment $[2,6]$

\begin{tabular}{|c|c|c|c|c|}
\hline Etiology & Diagnostics & $\begin{array}{l}\text { First-line antimicrobial } \\
\text { treatment }\end{array}$ & Other options & Comment \\
\hline \multicolumn{5}{|l|}{ Bacteria } \\
\hline $\begin{array}{l}\text { Pseudomonas } \\
\text { aeruginosa }\end{array}$ & Culture: sputum, BAL & $\begin{array}{l}\text { Pip/taz, carbapenems, } \\
\text { ceftazidime, cefepime }\end{array}$ & $\begin{array}{l}\text { Colistin, } \\
\text { ceftolozane/ } \\
\text { tazobactam }\end{array}$ & $\begin{array}{l}\text { Consider combination treatment } \\
\text { (aminoglycosides usually not } \\
\text { effective in pneumonia) }\end{array}$ \\
\hline $\begin{array}{l}\text { Escherichia coli and } \\
\text { Klebsiella pneumoniae } \\
\text { with ESBL production }\end{array}$ & Culture: sputum, BAL & Carbapenems & $\begin{array}{l}\text { Depends on } \\
\text { resistance pattern }\end{array}$ & \\
\hline $\begin{array}{l}\text { Stenotrophomonas } \\
\text { maltophilia }\end{array}$ & Culture: sputum, BAL & $\begin{array}{l}\text { High-dose TMP/ } \\
\text { SMX }\end{array}$ & $\begin{array}{l}\text { If TMP/SMX not } \\
\text { possible: consider } \\
\text { minocycline and } \\
\text { moxifloxacin }\end{array}$ & $\begin{array}{l}\text { In vitro susceptibility may not } \\
\text { reliably predict clinical effect }\end{array}$ \\
\hline $\begin{array}{l}\text { Staphylococcus aureus, } \\
\text { MSSA }\end{array}$ & Culture: sputum, BAL & Oxacillin & & Vancomycin inferior \\
\hline $\begin{array}{l}\text { Staphylococcus aureus, } \\
\text { MRSA }\end{array}$ & Culture: sputum, BAL & Vancomycin linezolid & & $\begin{array}{l}\text { Daptomycin should not be used } \\
\text { in pneumonia due to high failure } \\
\text { rate }\end{array}$ \\
\hline \multicolumn{5}{|l|}{ Fungus } \\
\hline $\begin{array}{l}\text { Pneumocystis jirovecii } \\
(P C P)\end{array}$ & PCR and IF: sputum, BAL & $\begin{array}{l}\text { High-dose TMP/ } \\
\text { SMX }\end{array}$ & $\begin{array}{l}\text { Primaquine }+ \\
\text { clindamycin } \\
\text { pentamidine }\end{array}$ & $\begin{array}{l}\text { Adjuvant treatment with } \\
\text { high-dose glucocorticoids } \\
\text { controversial }\end{array}$ \\
\hline Aspergillus species & $\begin{array}{l}\text { Culture and microscopy: } \\
\text { sputum, BAL } \\
\text { Biomarkers: serum, BAL } \\
\text { (PCR: BAL, biopsy) }^{\mathrm{b}}\end{array}$ & $\begin{array}{l}\text { Voriconazole, } \\
\text { isavuconazole }\end{array}$ & $\begin{array}{l}\text { Lipid formulations } \\
\text { of amphotericin B }\end{array}$ & $\begin{array}{l}\text { Combination voriconazole and an } \\
\text { echinocandin may be beneficiary } \\
\text { in severe infections }\end{array}$ \\
\hline Mucormycosis & $\begin{array}{l}\text { Culture and microscopy: } \\
\text { sputum, BAL } \\
\text { (PCR: BAL, biopsy) }^{\mathrm{b}}\end{array}$ & $\begin{array}{l}\text { Lipid formulations of } \\
\text { amphotericin B }\end{array}$ & Isavuconazole & $\begin{array}{l}\text { Posaconazole is also an option } \\
\text { but less well documented }\end{array}$ \\
\hline Fusarium species & $\begin{array}{l}\text { Culture and microscopy: } \\
\text { sputum, BAL } \\
\text { (PCR: BAL, biopsy) }^{\text {b }}\end{array}$ & $\begin{array}{l}\text { Voriconazole } \\
\text { lipid formulations of } \\
\text { amphotericin B }\end{array}$ & Posaconazole & \\
\hline \multicolumn{5}{|l|}{ Virus } \\
\hline Influenza & $\begin{array}{l}\text { PCR: nasopharyngeal swab, } \\
\text { BAL }\end{array}$ & Oseltamivir & & No controlled data \\
\hline $\begin{array}{l}\text { Respiratory syncytial } \\
\text { virus (RSV) }\end{array}$ & $\begin{array}{l}\text { PCR: nasopharyngeal swab, } \\
\text { BAL }\end{array}$ & Ribavirin & & $\begin{array}{l}\text { No controlled data. Ribavirin } \\
\text { likely reduces the risk of } \\
\text { progression from upper to lower } \\
\text { airway infection and the mortality } \\
\text { in lower tract infection }\end{array}$ \\
\hline Adenovirus & PCR & $\begin{array}{l}\text { Cidofovir or } \\
\text { brincidofovir }\end{array}$ & & No controlled data \\
\hline Cytomegalovirus (CMV) & PCR: BAL & $\begin{array}{l}\text { Ganciclovir possibly } \\
\text { with iv Ig }\end{array}$ & Foscarnet & $\begin{array}{l}\text { No controlled data. The value of } \\
\text { adding iv Ig is uncertain }\end{array}$ \\
\hline
\end{tabular}

Pip/taz piperacillin/tazobactam, TMP/SMX trimethoprim/sulfamethoxazole, $I F$ immunofluorescence, $I v$ intravenous

"Galactomannan, beta-glucan, lateral-flow device (see section "Fungal Infections")

'May be considered (see section "Fungal Infections")

age of other Gram-negative enteric bacteria, $S$. pneumoniae, $H$. influenzae, and $S$. aureus. Suitable options include piperacillin/tazobactam, cefepime, meropenem, and imipenem/cilastatin [6].

2. In non-neutropenic patients with communityacquired pneumonia, cefotaxime/ceftriaxone is a reasonable firsthand alternative if admitted to hospital, and amoxicillin/clavulanate or levofloxacin if treated as outpatients.

3. In patients with T-cell suppression, addition of trimethoprim/sulfamethoxazole (TMP/SMX) for empirical treatment of PCP should be considered if not on prophylaxis.

(b) Targeted treatment:

1. Targeted therapy is outlined in Table 38.4 (and in the sections "Fungal Infections" and "Viral Infections") [2, 6].

(c) Breakthrough infection or no response to empirical treatment:

1. A new thoracic CT scan should be performed to identify progression of infiltrates or new infiltrates compatible with invasive mold infection or 
PCP. It is also useful for deciding in which lobe(s) the BAL should be performed.

2. BAL should always be performed if no contraindication (Table 38.4).

3. Change to meropenem/imipenem if receiving piperacillin/tazobactam, cefepime, or ceftazidime.

4. Consider addition of voriconazole as empirical treatment of invasive aspergillosis in patients not receiving mold-active prophylaxis and lipid formulation of amphotericin B for coverage of other mold infections in patients receiving mold prophylaxis.

5. Consider adding a fluoroquinolone if not already been prescribed for prophylaxis.

6. Consider adding high-dose TMP/SMX if there is risk of PCP and/or Stenotrophomonas maltophilia.

\section{Cather-Related Bloodstream Infection (CRBSI)}

A. Epidemiology:

1. Different definitions of CRBSI exist, but common and clinical useful definitions are (1) growth in central blood culture at least $2 \mathrm{~h}$ before peripheral blood culture or (2) blood culture and catheter tip culture with growth of the same organism [7].

2. CRBSI is a well-recognized complication in hematologic patients with a reported incidence of up till 5.2 per 1000 catheter days. The causative organisms are most often coagulase-negative staphylococci, followed by Staphylococcus aureus, Candida species, and, more seldom, Gram-negative enteric bacteria, such as Klebsiella pneumoniae and Pseudomonas aeruginosa.

3. Appropriate preventive measures are important to minimize CRBSI and include both education of the healthcare personnel handling the central venous catheter (CVC) and application of aseptic bundles during the insertion and use of the CVC. In addition, assessment of the necessity of the CVC should be made routinely with prompt removal when not needed [8].

B. Diagnostics:

1. Most often, the only clinical sign is fever, sometimes accompanied by signs of local infection at the insertion site or tunnel.

2. Blood cultures are simultaneously drawn peripherally and from the central catheter, preferably one set of blood cultures per lumen.

3. If the differential in time to positivity (DTP) is $2 \mathrm{~h}$ or more in favor of blood cultures drawn through the CVC, CRBSI definitions are fulfilled [7].
4. A diagnose of catheter-related infection can also be made without positive blood culture if there are undisputable signs of infection (erythema, swollenness, pain) over the catheter tunnel or port pocket.

5. In the case of positive central blood cultures with an organism known to cause CRBSI, negative peripheral blood cultures, and no local signs of infection, a catheterrelated infection is suspected but not proven. A diagnostic algorithm in this scenario is outlined in Fig. 38.2.

C. Treatment: $[7,8]$

1. Catheter removal, together with targeted antimicrobial therapy, remains the mainstay of treatment of CRBSI. Removal should always be performed in septic, hypotensive patients, in patients with complicated CRBSI such as tunnel and port infections, and in CRBSI caused by Candida species.

2. Vancomycin should be added in septic, hypotensive patients with suspected CRBSI and/or local signs of infection such as tunnel infection, port abscesses, or cellulitis around insertion site.

3. In CBRSI caused by Pseudomonas aeruginosa and Staphylococcus aureus, removal of catheter is associated with lower relapse rates and better outcomes and should be performed routinely.

4. In CBRSI caused by other Gram negatives than Pseudomonas, antibiotic-lock therapy can be tried if removal of the catheter is not feasible.

5. In CRBS with coagulase-negative staphylococci and no local signs of infection, the catheter can often be retained with the use of antibiotic-lock therapy.

6. Antibiotic-lock therapy involves installing a high concentration of an antibiotic to which the causative microbe is susceptible in the catheter lumen. The solution should be left in the lumen without interruption for at least $8 \mathrm{~h}$ per $24 \mathrm{~h}$, but longer if possible. When using a catheter retaining strategy, 14 days of combined systemic therapy and antibiotic-lock therapy are usually recommended. When blood cultures become negative, iv therapy may be switched to oral.

7. If the catheter is removed and there are no signs of local or metastatic infection, treatment duration is usually 7 days, except for Staphylococcus aureus (14 days) and Candida species (14 days after first negative blood culture).

\section{Typhlitis (Neutropenic Enterocolitis)}

A. Typhlitis is a potentially serious complication in neutropenic patients characterized by fever, abdominal pain, and thickening of the cecum and adjacent ileum [9].

B. The pathogenesis involves intestinal damage associated with neutropenia and mucositis, followed by microbial invasion with inflammation and ulceration. 


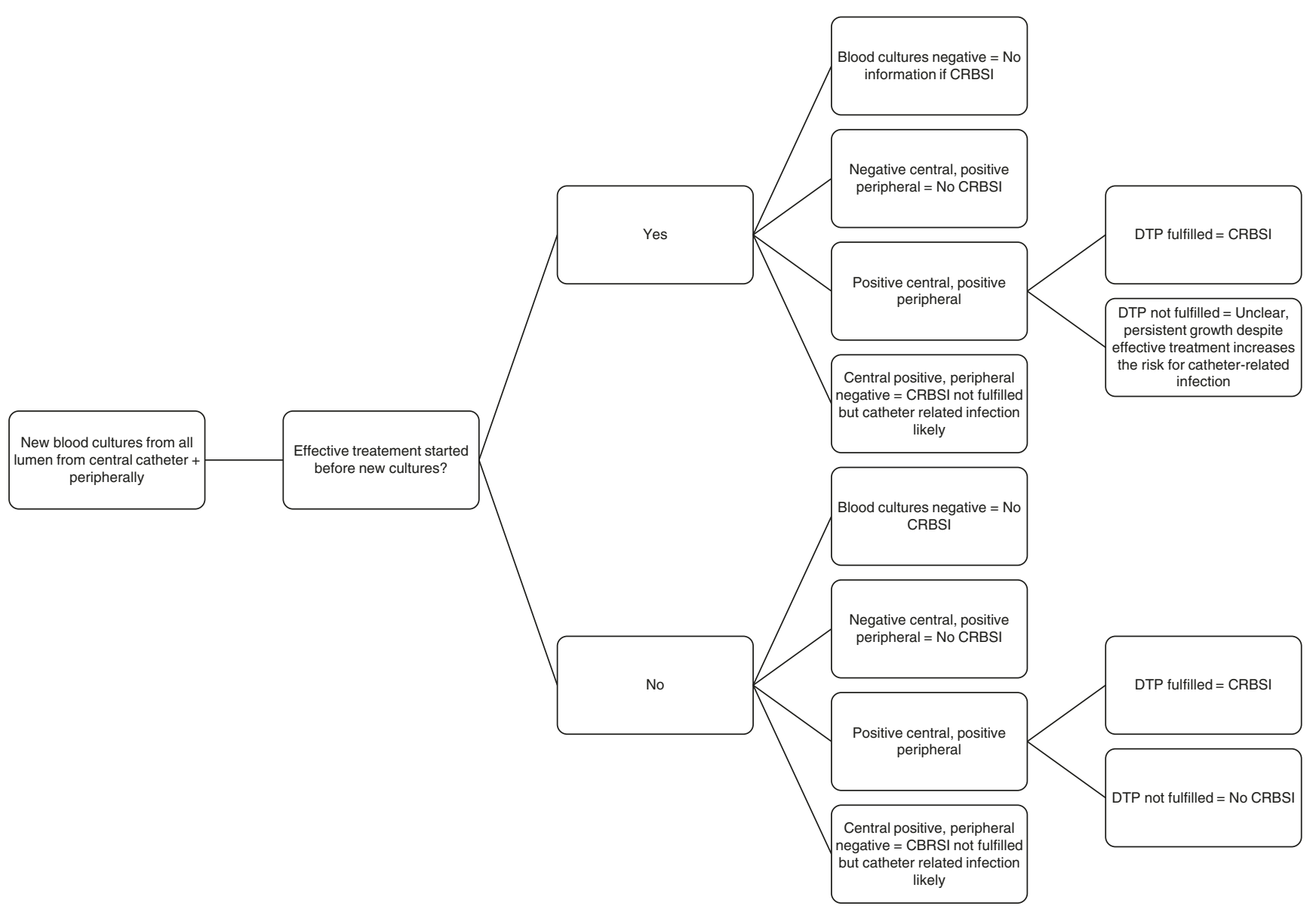

Fig. 38.2 Diagnostic algorithm for CRBSI. DTP differential in time to positivity, CRBSI catheter-related bloodstream infections

C. The reported incidence varies, depending on the definitions and intensity of chemotherapy, from $5 \%$ in all patients with hematologic malignancies up to $28 \%$ in patients with AML [9].

D. Ultrasound or CT scan showing bowel wall thickening in a neutropenic patient with fever and abdominal pain is diagnostic.

E. Blood cultures and Clostridium difficile assays should be performed, and antimicrobial treatment covering Gramnegatives, including Pseudomonas aeruginosa, and anaerobes should be instituted promptly. Suitable options include monotherapy with meropenem, imipenem/cilastatin, or piperacillin/tazobactam or a combination of cefepime and metronidazole.

F. Translocation of Candida species may occur, and empirical treatment/prophylaxis with a candida-active agent, such as fluconazole or an echinocandin, should be considered.

G. Bowel rest and G-CSF to shorten the duration of neutropenia may be considered, but evidence for effect are lacking.

H. Surgery should be avoided unless absolute necessary (perforation or massive bleeding) [9].

\section{Fungal Infections}

A. Empirical and preemptive antifungal therapy:

1. Epidemiology:

(a) Prolonged neutropenic fever despite broadspectrum antibiotic therapy is common, and empirical antifungal therapy based on this indication only will lead to administration of antifungals to around one third of neutropenic patients. However, the majority of these patients do not have an invasive fungal disease (IFD), and indiscriminate empirical antifungal therapy will thus expose patients to unnecessary and potentially harmful drugs.

(b) The incidence of IFD is approximately 5-10\% in high-risk patients receiving candida-active prophylaxis, such as AML/MDS patients receiving remission-intended chemotherapy. In patients receiving mold-active prophylaxis, usually posaconazole or voriconazole, the reported frequency of breakthrough IFD is considerably lower, between $0.5 \%$ and $1.5 \%$ [10]. 
(c) Patients anticipated to have a short period of neutropenia $(<10$ days) have a low risk of IFD, especially if receiving candida-active prophylaxis.

2. Diagnostics:

(a) Initial diagnostic workup includes blood cultures, a thoracic CT scan, and biomarkers in blood or serum (usually galactomannan (GM) and/or $(1 \rightarrow 3)-\beta$-D-glucan (beta-glucan); see sections "Invasive Aspergillosis" and "Invasive Candida Infections") [11].

(b) Many commercial blood culture systems have a good sensitivity for Candida species if no concomitant bacteremia, with the possible exception of Candida glabrata. Thus, if the suspicion of invasive Candida infection is high, or if concomitant bacteremia is suspected, blood cultures with better sensitivity for yeast ("mycosis bottles") should be included.

(c) In case of pulmonary infiltrates, a BAL should be performed (Table 38.4) [12].

(d) If no candida-active prophylaxis has been administered, CT scan of the abdomen, looking for signs of hepatosplenic candidiasis, may be considered.

(e) New skin lesion/nodules should be biopsied and sent for microscopy, cultures, and PCR.

3. Treatment:

(a) First-line options include lipid formulations of amphotericin B, an echinocandin, or voriconazole.

(b) The best choice of treatment in patients with suspected breakthrough infection while on moldactive treatment has not been evaluated in clinical trials, but a switch to another drug class is recommended. In patients receiving mold-active azoles, change to a lipid formulation of amphotericin $B$ is a logical choice as this gives a broad coverage against other mold infections than aspergillosis.

(c) The timing of empirical antifungal treatment depends on choice of strategy.

1. In the empirical approach, antifungal treatment is initiated after $72-96 \mathrm{~h}$ of neutropenic fever despite broad-spectrum antibiotics, even if there are no other signs or findings suggestive of IFD. As discussed above this approach will expose many patients to unnecessary and potentially harmful treatment and is not recommended.

2. In the preemptive approach, patients are screened in blood/plasma two to three times per week with one or more biomarkers, most often GM. If a biomarker becomes positive, a thoracic CT scan is performed, and if infil- trates are present, BAL are performed, and empirical antifungal therapy started. In patients with negative CT scans, screening with biomarkers continues, and no antifungals are started. If a biomarker becomes positive again, the procedure with a thoracic CT scan is repeated. Studies have shown that this approach significantly reduces the use of antifungals without reducing overall survival, although the frequency of diagnosed IFD was slightly higher than in the empirical arm [13].

3. In the diagnostic approach, biomarkers and thoracic CT scans are performed in high-risk patients with neutropenic fever for more than 3-5 days despite broad-spectrum antibiotics. If infiltrates are found, a BAL should be performed. If both biomarkers and $\mathrm{CT}$ scan are negative and the patient is stable, empirical antifungal therapy can be withheld.

(d) In high-risk neutropenic patients deteriorating despite broad-spectrum antibiotics, empirical antifungal treatment should be initiated even if the diagnostic work-up for IFD is negative.

(e) The duration of empirical treatment should be as short as possible, and no longer than until resolution of neutropenia, if no IFD has been diagnosed.

B. Invasive Candida infections:

1. Epidemiology:

(a) Candidemia in neutropenic patients is a lifethreatening infection, which can lead to acute disseminated candidiasis, a sepsis-like syndrome, and death [14].

(b) Chronic disseminated candidiasis (hepatosplenic candidiasis) can occur as a complication of candidemia in neutropenic patients.

(c) Important risk factors are increased colonization of the gastrointestinal tract and other mucosal surfaces by Candida species, disruption of the protective mucosal barrier due to chemotherapy, and decreased phagocytic capacity due to neutropenia.

(d) The incidence depends on the depth and duration of neutropenia, on the degree of mucosal disruption, and whether prophylaxis has been administered.

(e) For recommendations of prophylaxis, please see Table 38.5.

2. Diagnostics:

(a) Most often the only symptom in candidemia is fever. Right upper quadrant discomfort, fever, nausea, and elevation of liver enzymes after reso- 
Table 38.5 Recommended anti-fungal prophylaxis [10]

\begin{tabular}{|c|c|c|c|c|}
\hline Risk classification & Clinical examples & Type of prophylaxis & First-line agent & Alternative agents \\
\hline \multirow[t]{4}{*}{ High risk } & $\begin{array}{l}\text { Acute leukemia or myelodysplasia with } \\
\text { remission intended treatment, }\end{array}$ & \multirow[t]{4}{*}{$\begin{array}{l}\text { Anti-mold and } \\
\text { anti-candida }\end{array}$} & \multirow[t]{4}{*}{$\begin{array}{l}\text { Posaconazole } \\
\text { (Fluconazole) }^{\mathrm{c}}\end{array}$} & 1. Voriconazole \\
\hline & Severe GVHD & & & 2. Liposomal AmB \\
\hline & Extensive chronic GVHD & & & itraconazole, echinocandins, \\
\hline & Extensive T-cell directed therapy ${ }^{\mathrm{b}}$ & & & $\begin{array}{l}\text { aerosolized liposomal AmB } \\
\text { (+ fluconazole) }\end{array}$ \\
\hline \multirow[t]{3}{*}{ Low risk } & Autologous HSCT & \multirow[t]{3}{*}{ Anti-candida } & \multirow[t]{3}{*}{ Fluconazole } & Echinocandins \\
\hline & Allogeneic HSCT without GVHD & & & Itraconazole \\
\hline & $\begin{array}{l}\text { Intensive/dose-escalating therapy for } \\
\text { lymphoma }\end{array}$ & & & \\
\hline \multirow[t]{3}{*}{ Very low risk } & Standard therapy for lymphoma & \multirow[t]{3}{*}{ None } & & \\
\hline & Chronic myeloid leukemia & & & \\
\hline & Other myeloproliferative neoplasms & & & \\
\hline
\end{tabular}

$G V H D$ graft-versus-host disease, $A m B$ amphotericin B

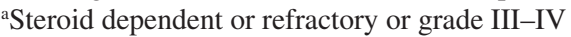

${ }^{\mathrm{b}}$ Such as T-cell-directed antibodies (thymoglobulin, alemtuzumab) and/or prolonged treatment with high-dose corticosteroids

'Only if low incidence of mold infections. May also be given as part of an integrated care strategy together with a mold-directed diagnostic approach (includes weekly screening with biomarkers during periods of high risk)

lution of neutropenia are the most common findings in chronic disseminated candidiasis.

(b) Cultures of blood, and other samples collected under sterile conditions, are the diagnostic gold standard for invasive candidiasis and should always be performed. However, since cultures are hampered by low sensitivity (overall sensitivity for blood cultures is estimated to be around 50\%), several other diagnostic tests have been developed [14].

1 . $(1 \rightarrow 3)-\beta-D-G l u c a n$ (beta-glucan) is a cell wall constituent of Candida species, Aspergillus species, Pneumocystis jirovecii, and several other fungi. Beta-glucan detection in plasma may detect cases of invasive candidiasis days to weeks prior to positive blood cultures and shorten the time to initiation of antifungal therapy. However, a positive result should be interpreted with caution because of a low positive predictive value due to poor specificity. Moreover, true-positive results are not specific for invasive candidiasis, but rather suggest the possibility of an invasive fungal infection.

2. Candida PCR in blood has been shown to be helpful but comparisons have been hampered by lack of standardization. The FDA approved a commercial Candida PCR in 2014, but clinical data is limited.

(c) In hepatosplenic candidiasis contrast-enhanced CT, MRI, PET-CT, and ultrasound can all be used for identification of microabscesses in the liver and spleen.

(d) Abscesses and metastatic embolus to the skin should be biopsied and sent for microscopy, culture, and PCR.
3. Treatment:

(a) Recommendation of antifungal treatment and duration is outlined in Table $38.6[14,15]$.

C. Invasive Aspergillosis (IA):

1. Epidemiology:

(a) Aspergillus species and other filamentous fungi are ubiquitous in the environment. Inhalation of fungal spores is the most common portal of entry and sinopulmonary disease the most frequent clinical manifestation. Dissemination can occur through hematogenous spread [16].

(b) The most important risk factors are prolonged neutropenia and T-cell impairment.

(c) Patients at high risk include those receiving induction therapies for AML/MDS, especially in those with refractory or relapsed acute leukemia.

(d) Patients undergoing allogeneic hematopoietic cell transplant (HCT) have an increased risk of IA, with the most important risk factors being the severity and duration of graft-versus-host disease [17].

(e) Prevention includes reducing exposure to fungal spores (such as hospital rooms with highefficiency particular air (HEPA) filtration, avoiding gardening and construction sites) and administration of mold-active prophylaxis to patients at high risk (Table 38.5).

2. Diagnostics:

(a) The diagnosis of IA is based on the combination of radiology and microbiological findings in a susceptible host and is often challenging to reach.

(b) The clinical presentation is usually fever with or without cough, hemoptysis, and pleural pain. 
Table 38.6 Treatment of invasive Candida infections [14]

\begin{tabular}{|c|c|c|c|}
\hline & Candidemia, non-neutropenia & Candidemia, neutropenia & Hepatosplenic candidiasis \\
\hline \multicolumn{4}{|l|}{ Treatment } \\
\hline \multirow[t]{2}{*}{ Initial } & 1. An echinocandin & 1. An echinocandin & \multirow{2}{*}{$\begin{array}{l}\text { 1. Lipid formulation of } \mathrm{AmB}(3-5 \mathrm{mg} / \mathrm{kg}) \\
\text { or an echinocandin }\end{array}$} \\
\hline & $\begin{array}{l}\text { 2. Fluconazole (only if stable } \\
\text { and no azole prophylaxis) }\end{array}$ & 2. Lipid formulation AmB (3-5 mg/kg) & \\
\hline Step-down & $\begin{array}{l}\text { Fluconazole in clinically } \\
\text { stable patients with } \\
\text { susceptible isolates }\end{array}$ & $\begin{array}{l}\text { Fluconazole (or voriconazole if mold } \\
\text { coverage is wanted) can be used during } \\
\text { persistent neutropenia in clinically stable } \\
\text { patients with susceptible isolates }\end{array}$ & $\begin{array}{l}\text { After several weeks of AmB or an } \\
\text { echinocandin treatment may be changed } \\
\text { to fluconazole in patients who are unlikely } \\
\text { to have a fluconazole-resistant isolate }\end{array}$ \\
\hline Duration & $\begin{array}{l}14 \text { days after first negative } \\
\text { blood culture if no metastatic } \\
\text { complication }\end{array}$ & $\begin{array}{l}\text { Until resolution of neutropenia, but not } \\
\text { shorter than } 14 \text { days after first negative } \\
\text { blood culture if no metastatic } \\
\text { complication }\end{array}$ & $\begin{array}{l}\text { Until lesions resolve on repeat imaging, } \\
\text { usually several months }\end{array}$ \\
\hline $\begin{array}{l}\text { Ophthalmological } \\
\text { examination }\end{array}$ & $\begin{array}{l}\text { Yes, within the } 1 \text { st week } \\
\text { after diagnosis }\end{array}$ & $\begin{array}{l}\text { Yes, within the } 1 \text { st week after resolution } \\
\text { of neutropenia }\end{array}$ & Yes, as part of the investigation \\
\hline CVC removal & $\begin{array}{l}\text { Most often but } \\
\text { individualized decision, as } \\
\text { early as possible if CVC is } \\
\text { thought be the source }\end{array}$ & $\begin{array}{l}\text { More seldom as the dominating source is } \\
\text { the gastrointestinal tract }\end{array}$ & Individualized decision \\
\hline
\end{tabular}

$A m B$ amphotericin B, $C V C$ central venous catheter

(c) A thoracic CT scan should always be performed. Typical findings include nodules, consolidative lesions, wedge-shaped infarcts, and the halo sign: a nodule $>1 \mathrm{~cm}$ in diameter surrounded by a groundglass opacity reflecting hemorrhage $[16,18]$.

(d) Diagnostic BAL should always be performed unless contraindicated (Table 38.4), and sputum should be sent for microscopy and culture $[12,16]$.

(e) Since the diagnostic yield of microscopy and culture is limited, other tests have been developed. All the available tests have weaknesses and best results have been reported when combining two (or more) tests [11, 19].

1. Galactomannan (GM) antigen test is the most used. GM constitutes part of the Aspergillus fungal wall and can be detected in serum and BAL (and in CSF) with a commercial test that is FDA approved. In neutropenic hematology patients, the sensitivity is around $70 \%$ when tested in serum and higher in BAL. In patients receiving mold-active treatment, the sensitivity is significantly reduced.

2. Aspergillus-specific lateral-flow device is an antigen test with a performance similar to GM with the advantage of providing a test result within minutes but is not as well documented [19].

3. Beta-glucan (see also section "Invasive Candida Infections") has a sensitivity similar or just below the one of GM but poor specificity due to high rate of false-positive results and because a true-positive test is not specific for
Aspergillus species. A commercial test is available and has FDA approval.

4. PCR in blood and BAL have been shown to have a diagnostic performance comparable to GM, and combined negative GM and PCR tests in BAL performed in a patient not receiving mold-active treatment have a high negative predictive value. However, until recently few of the PCR assays had been standardized and validated, and since no assay has been approved by the FDA, it is difficult to recommend PCR for routine use as of yet [20,21].

3. Treatment:

(a) First-line treatment is voriconazole or isavuconazole, with isavuconazole generally being better tolerated. Therapeutic drug monitoring is generally recommended when using mold-active azoles to make sure that therapeutic levels are reached $[15,16,22]$.

(b) Alternative treatment is lipid formulations of amphotericin B[16].

(c) Primary therapy with a combination of voriconazole and an echinocandin may be considered in patients with severe disease, especially if profound and prolonged neutropenia.

(d) The clinical course depends on the duration and severity of neutropenia. The size of the lesions usually increases during the 1st week of treatment and then remains stable for another week. Repetition of CT scan is not recommended before 2 weeks after the start of treatment unless clinical deterioration is seen. 
(e) Treatment duration is minimum 6-12 weeks but depends on the underlying disease and immunodeficiency. Patients who require subsequent immunosuppression should receive secondary prophylaxis to prevent recurrence $[15,16]$.

(f) Adjunctive measures should be considered: Ongoing immunosuppression should be minimized or eliminated altogether if possible, colonystimulating factors may be considered in neutropenic patients, and granulocyte transfusion may be considered in refractory infections.

D. Other mold infections of importance:

1. Epidemiology:

(a) Other mold infections than IA are seen in around $15 \%$ of all invasive mold infections, either alone or in combination with IA [22].

(b) Mucormycosis (formerly known as zygomycosis) is caused by members of the order Mucorales and is the dominating etiology to non-IA mold infections. Mucormycosis is very aggressive with reported mortality rates between $24 \%$ and $49 \%$.

(c) Fusariosis is caused by an invasive infection with Fusarium species and is the second most common non-IA mold infection. The outcome is usually poor, and largely dependent on the recovery of the immune status of the host, particularly neutropenia [23].

(d) Risk factors for non-IA mold infections are the same as for IA, i.e., prolonged neutropenia and T-cell suppression.

2. Diagnostics:

(a) The most common manifestations of mucormycosis are rhino-cerebral and pulmonary infections. Diagnostics rely on radiology in combination with microscopy and culture of biopsies and BAL. PCR may be considered, but no commercial test approved by FDA exists. Typical findings on CT scan are the same as for IA, except that the reversed halo sign, an area of ground-glass opacity surrounded by a ring of consolidation, is more frequent in mucormycosis and thus suggestive of the disease. Negative GM and aspergillus PCR in a BAL performed on suspicion of mold infection is also suggestive of non-IA infections such as mucormycosis.

(b) Fusariosis in hematology patients is most often disseminated, and pulmonary lesions are found in almost $50 \%$ of cases. The radiologic picture is similar to IA. Nodular and papular skin lesions (which should be biopsied) are common and blood cultures are often positive. Fusarium species interact with the GM test so that the test may become positive even in the absence of concomitant IA [23].
3. Treatment:

(a) Mucormycosis is a very aggressive infection in hematology patients and treatment must be initiated promptly. First-line agent is high-dose liposomal amphotericin B combined with surgery. Isavuconazole has recently been evaluated (retrospectively) and was found to have an efficacy similar to that of liposomal amphotericin $B$ and is an option if liposomal amphotericin $B$ cannot be used. Surgery should be performed if possible [15, 17, 24].

(b) The drug of choice for the treatment of invasive fusariosis is either voriconazole or liposomal amphotericin $B$ [23].

E. Pneumocystis jirovecii pneumonia (PCP):

1. Epidemiology:

(a) Transmission of Pneumocystis jirovecii occurs during the first years of life via person-to-person contacts, usually asymptomatically or as mild infection of the upper respiratory tract.

(b) P. jirovecii pneumonia (PCP or PJP) carries a high mortality in hematology patients and early recognition and treatment are critical for successful outcome [25].

(c) PCP can occur both from previous colonization and from new person-to-person transmission.

(d) Prophylaxis should be administered to patients at risk such as acute lymphoblastic leukemia (ALL), allogeneic HCT, >4 weeks of treatment with corticosteroids ( $\geq 20 \mathrm{mg} /$ day prednisone), treatment with alemtuzumab, and treatment with fludarabine/cyclophosphamide/rituximab. Prophylaxis should also be considered in patients with other risk factors, such as treatment for lymphoma [25, 26].

(e) First-line prophylaxis is TMP/SMX. Second-line choices include aerosolized pentamidine, dapsone, and atovaquone [26].

2. Diagnostics [27]:

(a) Clinical presentation is most often fever, nonproductive cough, dyspnea, and/or impaired oxygenation.

(b) Chest X-ray has low sensitivity. Thoracic CT scan usually shows bilateral, patchy ground-glass opacities, predominantly in the perihilar regions. However, the radiology findings are non-specific, so to establish the diagnosis of PCP, the pathogen must be identified.

(c) Identification of P. jirovecii can be difficult because hematology patients generally have a lower fungal load than non-hematology patients have.

(d) BAL is the preferred specimen since a gradient of fungal load is expected with the highest load in 
$B A L$ fluid and the lowest in upper respiratory sample. In addition, BAL can identify other pathogens, which is important since coinfection is common in patients with PCP. If BAL cannot be performed, sputum, preferably induced sputum, is preferred over other upper respiratory specimens such as oral washing, nasopharyngeal swabs, or nasal swabs.

(e) P. jirovecii cannot be cultivated, and identification is based on PCR and microscopy using immunofluorescence (IF) techniques.

(f) PCR has higher sensitivity than IF, but a positive result may be difficult to reliably discriminate between colonization and infection.

(g) A positive IF corresponds to diagnose of PCP regardless of specimen.

(h) PCP is ruled out if PCR is negative in BAL, whereas a negative PCR test in sputum or other upper respiratory samples does not rule out infection.

(i) The combination of a positive PCR and negative IF cannot distinguish between colonization and infection.

(j) A negative test for serum beta-glucan has a high negative predictive value.

3. Treatment [28]:

(a) Treatment should be instituted promptly to optimize the chance of successful outcome.

(b) First-line treatment is high-dose iv TMP/SMX for $\geq 14$ days, followed by prophylaxis until immunosuppression is resolved.

(c) Second-line treatments include oral primaquine $+i v$ or oral clindamycin, iv pentamidine, and oral atovaquone. (d) Administration of glucocorticoids cannot be generally recommended and must be based on caseby-case basis.

\section{Viral Infections}

\section{A. Epidemiology}

Viral infections can broadly be divided into latent/persistent viruses that after primary infection remain in the patient for many years/for life and viruses that are only present for a short period (days-weeks). Viral infections are particularly important in the most immunocompromised especially allogeneic HCT. Many different viruses can cause the same clinical syndromes (Table 38.7), and therefore specific diagnostic procedures are required to allow correct management.

B. Diagnosis

1. Detection of antibodies

Detection of antibodies as evidence of infection is a standard technique in healthy immune competent individuals with IgM as a sign of recent infection and IgG as evidence of past infections. In hematology patients, serology is rarely useful for diagnosis of ongoing infection but is very important in determining risks for viral infections occurring posttransplantation.

2. Detection of viruses or viral components

Traditional virus isolation in cell culture is rarely performed today. Instead methods detecting viral antigens or nucleic acids (nucleic acid testing - NAT) have become the standard for virus identification. NAT can also be used to determine viral load and through mutation analysis/sequencing detect resistance against antiviral drugs.

3. Diagnosis on tissue

Table 38.7 Clinical syndromes and possible viral pathogens (incomplete list)

\begin{tabular}{l|l|l|l}
\hline Pneumonia & Encephalitis & Hepatitis & GI disease \\
\hline CMV & HHV-6 & CMV & CMV \\
\hline Influenza & Adenoviruses & EBV & HSV \\
\hline Adenoviruses & HSV & Adenoviruses & Adenoviruses \\
\hline RSV & VZV & HBV & EBV \\
\hline Parainfluenza & CMV & HCV & VZV \\
\hline Metapneumovirus & Measles & VZV & Rotaviruses \\
\hline Coronaviruses & JCV & HAV & Noroviruses \\
\hline Rhinoviruses & EBV & HEV & Astroviruses \\
\hline Measles & Rabies & & \\
\hline BZV & West Nile virus & & \\
\hline
\end{tabular}

GI disease gastrointestinal disease, $C M V$ cytomegalovirus, $H H V$-6 human herpes virus 6, $E B V$ Epstein-Barr virus, $H S V$ herpes simplex virus, $R S V$ respiratory syncytial virus, $V Z V$ varicella zoster virus, $H B V$ hepatitis B virus, $H C V$ hepatitis $\mathrm{C}$ virus, $J C V$ JC virus, $H A V$ hepatitis A virus, $H E V$ hepatitis E virus 
To diagnose end-organ disease, virus should be detected in the affected organ preferably by specific staining of tissue.

C. Herpesviruses

Herpesviruses are latent/persistent viruses and frequently reactivate in immunosuppressed patients.

Herpes simplex virus (HSV)-1 and HSV-2:

(a) The rates of seropositivity in the population increase with age. HSV-1 usually causes localized infections in the orofacial area but can occur in other locations. HSV-2 usually causes localized infections in the urogenital tract. HSV-1 encephalitis is the most severe manifestation but is rare in hematology patients as in the normal population. HSV-2 can cause meningitis.

(b) NAT is the diagnostic method of choice for both viruses.

(c) Prophylaxis against HSV-1 and HSV-2 with acyclovir/valaciclovir is recommended to all seropositive patients undergoing HSCT and should be considered for other intensively treated hematology patients. These drugs are also first choice for treatment [29].

(d) Resistance to acyclovir can develop and occurs in approximately 5-15\% of patients depending on risk profile. Foscarnet is the first-line treatment for acyclovir-resistant virus.

D. Cytomegalovirus (CMV):

(e) The rate of CMV seropositivity increases with age and varies with geographical location. CMV seropositivity is a risk factor for non-relapse mortality and decreased survival after allogeneic HCT. A $C M V$-seronegative donor should, if available, be used for a $C M V$-seronegative patient [30-32].

(f) Approximately $60 \%$ of $C M V$-seropositive patients develop active CMV infection after HSCT, most commonly during the first 2 months, while the risk for a CMV-seronegative patient receiving a graft from a CMV-seropositive donor is approximately $30 \%$. For other hematology patients and patients undergoing autologous HSCT, the risks are much lower. Patients receiving anti-T-cell therapy are at an increased risk.

(g) Most CMV infections are asymptomatic or cause low-grade fever possibly with depressed bone marrow function. End-organ CMV disease occurs in 2-10\% of HSCT patients, most commonly gastrointestinal disease. CMV pneumonia is still associated with a high mortality. Other end-organ manifestations are retinitis, hepatitis, and encephalitis. Risk factors are allogeneic HCT, acute GVHD, and intensive T-cell suppression. CMV end-organ disease in other groups of hematology patients is uncommon [30]. (h) Weekly blood monitoring of allogeneic HCT patients is recommended using either quantitative PCR or the pp65 antigenemia assay. No fixed cutoff can be recommended since it depends on the risk profile of the patient and the exact assay used, but many centers use cutoffs around $1000 \mathrm{IU} / \mathrm{ml}$ [33].

(i) Monitoring is not routinely recommended for autologous HCT patients or other hematology patients. There is no information regarding cutoffs for therapy in these types of patients.

(j) The diagnosis of CMV disease requires symptoms and/or signs + CMV detected from the involved organ. CMV in blood combined with symptoms from an organ is not enough for making the diagnosis CMV disease [30, 34].

(k) Possible strategies for management are prophylaxis, preemptive therapy, and treatment of end-organ disease.

(1) Letermovir has been shown to be effective as prophylaxis reducing the risk for clinically significant CMV infection and can also reduce all-cause mortality [35].

(m) Preemptive therapy based on detection of CMV by monitoring is an effective strategy in high-risk patients such as allogeneic HCT recipients. Ganciclovir and valganciclovir are first-line drugs for treatment of CMV infection and disease. Highdose iv immunoglobulin (Ig) has been used in combination with ganciclovir or treatment of CMV pneumonia, but its usefulness has not been proven in studies [33].

(n) Antiviral resistance develops in $0-10 \%$ of patients depending on their risk profile. Secondline drugs are foscarnet and cidofovir. The main limitation with these drugs is side effects. Case reports and small case series exist with the use of leflunomide or artesunate for resistant and refractory $C M V$.

(o) CMV specific T-cells are an option if available.

(p) New antivirals are currently undergoing clinical development (maribavir, letermovir, brincidofovir).

E. Varicella-zoster virus (VZV):

(a) VZV causes to different diseases: primary VZV infection causes chickenpox and reactivation of $V Z V$ causes herpes zoster (HZ, shingles).

(b) In countries not using general vaccination of children, most individuals have experienced chickenpox in childhood.

(c) Chickenpox can become severe in immunocompromised individuals.

(d) The risk for $H Z$ increases with age and is also increased in immunocompromised individuals. 
(e) Most HZ cases are self-limiting and give local symptoms. However, disseminated infections mimicking primary varicella and visceral cases sometimes without skin rash occur with poor outcome unless rapidly diagnosed and treated.

(f) Most cases can be easily recognized by the characteristic rash. PCR from the vesicular rash is the diagnostic method of choice, but immunofluorescence might also be used. PCR on blood is useful in the diagnosis of visceral cases.

(g) Acyclovir and valaciclovir (valacyclovir) are the drugs of choice for prevention and treatment of VZV infections. Prophylaxis is recommended in patients at high risk for $\mathrm{HZ}$ such as $\mathrm{HSCT}$ recipients and myeloma patients treated with proteasome inhibitors. IV acyclovir should be given to patients with primary varicella and to disseminated and visceral $H Z$ cases [36].

(h) Management of severe local HZ such as zoster ophthalmicus and zoster oticus needs close collaboration with appropriate specialists.

F. Epstein-Barr virus (EBV):

(a) The rate of seropositivity increases with age and most adults are seropositive. EBV constantly replicates in seropositive individuals without causing symptoms.

(b) End-organ EBV disease including meningitis, hepatitis, and pneumonia occurs but is rare also in severe immunocompromised individuals.

(c) The most important complication to EBV is posttransplant lymphoproliferative disease (PTLD) occurring in high-risk allogeneic HCT recipients.

(d) EBV can also be a trigger of hemophagocytic lymphohistiocytosis $(\mathrm{HLH})$ in patients with hematologic malignancies.

(e) In high-risk allogeneic HCT patients, monitoring in blood with quantitative PCR is indicated. There is no established cutoff since there is no standardized test [37].

(f) Symptoms and signs of PTLD are unspecific. Increased LDH, lymphadenopathy, and fever are common. CT scan for detection of splenomegaly and/ or intrathoracic or intra-abdominal lymphadenopathy should be considered. Biopsy of lymph nodes is needed to prove the diagnosis.

(g) There is no specific antiviral therapy effective against $E B V$.

(h) Rituximab is the preferred intervention both for preemptive therapy against EBV PTLD based on increasing EBV viral load and for treatment of established PTLD [37].

(i) Reduction of immunosuppression should be attempted if possible [37].

(j) EBV-specific T-cells are an option if available.
G. Other herpesviruses

Human herpesviruses (HHV)-6 A and B are the most common cause of viral encephalitis after allogeneic HCT. Their importance in other hematology patients is less well defined. The diagnosis is made by MRI + PCR on cerebrospinal fluid. Available antiviral drugs for treatment are foscarnet and ganciclovir/valganciclovir [38].

H. Community-acquired respiratory viruses:

(a) Respiratory viruses circulate in the community, and the risk for patients with hematological diseases to become infected reflects the local epidemiology. Respiratory syncytial virus (RSV), influenza viruses, and adenoviruses are best known to be able to cause disease in hematology patients, but reports of severe disease have been also reported with many other respiratory viruses including parainfluenza viruses, metapneumoviruses, and rhinoviruses. Nosocomial spread occurs which is why infection control is paramount. Most infections are mild and self-limiting, but severe infections can occur especially in allogeneic $H C T$ recipients and patients receiving intensive immunosuppressive therapy [39-42].

(b) The diagnosis is in most centers based on multiplex PCR on respiratory samples either from the upper airways (nasal, nasopharyngeal, or throat samples) or from the lower respiratory tract (BAL fluid). Most existing assays can detect 10-15 different respiratory viruses. Other techniques can be used such as antigen tests and immunofluorescence but have limitations most important that they detect only one virus.

(c) The most important part of management is prevention including avoiding infected individuals, handwashing, and influenza vaccination of patients, family members, and staff. It should be recognized that these infections can be spread by individuals having very limited symptoms.

(d) If an allogeneic HCT candidate presents before start of conditioning with symptomatic infection with a respiratory virus, postponing the transplant should be considered.

(e) Antiviral therapy has a limited role in most of these patients but can be considered in the most severely immunocompromised patients such as allogeneic HCT patients.

(f) Therapeutic options with data supporting efficacy, although there are no controlled studies, are ribavirin for RSV, neuraminidase inhibitors for influenza, and cidofovir/brincidofovir for adenovirus infections.

I. Hepatitis viruses

Several different viruses can cause liver disease in hematology patients with the most important being hepatitis $B$ 
and $C$. These viruses are significant pathogens in patients with hematological diseases and screening should always be performed. Increasing evidence implicates hepatitis $E$ virus (HEV) as an important pathogen and that this virus can be transmitted through blood products [43].

1. Hepatitis B virus (HBV):

(a) $H B V$ infection is widely distributed in the world with varying prevalence in different populations. Chronic infections are associated with liver cirrhosis and the development of hepatocellular cancer.

(b) Immunosuppressive therapy is associated with $H B V$ reactivation in chronically infected individuals. $H B V$ reactivation can result in severe liver disease including liver failure.

(c) Reactivation is more common in HBsAg-positive individuals but also HBsAg-negative individuals; anti-HBc-positive individuals receiving intensive immunosuppression such as after HSCT or anti-Bcell antibodies can reactivate $H B V$.

(d) Patients with high risk for reactivation should receive antiviral prophylaxis against $H B V$.

2. Hepatitis $\mathrm{C}$ virus (HCV):

(a) HCV infection is widely distributed in the world with varying prevalence in different populations. $\mathrm{HCV}$ infection is associated with an increased risk for non-Hodgkin lymphoma, and chronic HCV infection is associated with liver cirrhosis and hepatocellular cancer.

(b) Chronically infected patients with HCV can have flare-ups of liver disease during immunosuppressive therapy, and liver monitoring is therefore indicated.

(c) Antiviral therapy for $\mathrm{HCV}$ infection is rapidly evolving, and expert advice regarding treatment options should therefore be obtained.

J. Other viruses

Many different viruses can cause symptomatic infections in hematology patients. These include the polyomaviruses (JC and BK) [44], viruses causing gastroenteritis outbreaks (norovirus, rotavirus), and viruses spread through mosquito bites (yellow fever, dengue, Zika, chikungunya). The knowledge about the clinical importance of these viruses is limited, but it is likely that severe disease can develop in the most severely immunocompromised patients.

\section{Summary}

Early diagnosis and specific treatment are key factors in reducing the morbidity and mortality of infections in hematology and HCT patients. The rise of multiresistant organ- isms is a major threat and infection control is therefore of uttermost importance.

\section{References}

1. Legrand M, Max A, Peigne V, et al. Survival in neutropenic patients with severe sepsis or septic shock. Crit Care Med. 2012;40(1):43-9.

2. Averbuch D, Cordonnier C, Livermore DM, et al. Targeted therapy against multi-resistant bacteria in leukemic and hematopoietic stem cell transplant recipients: guidelines of the 4th European Conference on Infections in Leukemia (ECIL-4, 2011). Haematologica. 2013;98(12):1836-47.

3. Blennow $\mathrm{O}$, Ljungman $\mathrm{P}$. The challenge of antibiotic resistance in haematology patients. Br J Haematol. 2016;172(4):497-511.

4. Freifeld AG, Bow EJ, Sepkowitz KA, et al. Clinical practice guideline for the use of antimicrobial agents in neutropenic patients with cancer: 2010 update by the infectious diseases society of America. Clin Infect Dis. 2011;52(4):e56-93.

5. Flowers CR, Seidenfeld J, Bow EJ, et al. Antimicrobial prophylaxis and outpatient management of fever and neutropenia in adults treated for malignancy: American Society of Clinical Oncology clinical practice guideline. J Clin Oncol. 2013;31(6):794-810.

6. Maschmeyer G, Donnelly JP. How to manage lung infiltrates in adults suffering from haematological malignancies outside allogeneic haematopoietic stem cell transplantation. Br J Haematol. 2016;173(2):179-89.

7. Mermel LA, Allon M, Bouza E, et al. Clinical practice guidelines for the diagnosis and management of intravascular catheter-related infection: 2009 update by the Infectious Diseases Society of America. Clin Infect Dis. 2009;49(1):1-45.

8. Zakhour R, Chaftari AM, Raad II. Catheter-related infections in patients with haematological malignancies: novel preventive and therapeutic strategies. Lancet Infect Dis. 2016;16(11):e241-e50.

9. Sullivan PS, Moreno C, Shaib WL. Management of anorectal and intra-abdominal infections in the neutropenic cancer patient. Curr Probl Cancer. 2015;39(5):274-86.

10. Cornely OA, Maertens J, Winston DJ, et al. Posaconazole vs. fluconazole or itraconazole prophylaxis in patients with neutropenia. $\mathrm{N}$ Engl J Med. 2007;356(4):348-59.

11. Boch T, Spiess B, Cornely OA, et al. Diagnosis of invasive fungal infections in haematological patients by combined use of galactomannan, 1,3-beta-D-glucan, Aspergillus PCR, multifungal DNAmicroarray, and Aspergillus azole resistance PCRs in blood and bronchoalveolar lavage samples: results of a prospective multicentre study. Clin Microbiol Infect. 2016;22(10):862-8.

12. Maertens J, Maertens V, Theunissen K, et al. Bronchoalveolar lavage fluid galactomannan for the diagnosis of invasive pulmonary aspergillosis in patients with hematologic diseases. Clin Infect Dis. 2009;49(11):1688-93.

13. Cordonnier C, Pautas C, Maury S, et al. Empirical versus preemptive antifungal therapy for high-risk, febrile, neutropenic patients: a randomized, controlled trial. Clin Infect Dis. 2009;48(8):1042-51.

14. Pappas PG, Kauffman CA, Andes DR, et al. Clinical practice guideline for the management of candidiasis: 2016 update by the Infectious Diseases Society of America. Clin Infect Dis. 2016;62(4):e1-50.

15. Tissot F, Agrawal S, Pagano L, et al. ECIL-6 guidelines for the treatment of invasive candidiasis, aspergillosis and mucormycosis in leukemia and hematopoietic stem cell transplant patients. Haematologica. 2017;102(3):433-44.

16. Patterson TF, Thompson GR 3rd, Denning DW, et al. Practice guidelines for the diagnosis and management of aspergillosis: 2016 update by the Infectious Diseases Society of America. Clin Infect Dis. 2016;63(4):e1-e60. 
17. Cornely OA, Arikan-Akdagli S, Dannaoui E, et al. ESCMID and ECMM joint clinical guidelines for the diagnosis and management of mucormycosis 2013. Clin Microbiol Infect. 2014;20(Suppl 3):5-26.

18. De Pauw B, Walsh TJ, Donnelly JP, et al. Revised definitions of invasive fungal disease from the European Organization for Research and Treatment of Cancer/Invasive Fungal Infections Cooperative Group and the National Institute of Allergy and Infectious Diseases Mycoses Study Group (EORTC/MSG) Consensus Group. Clin Infect Dis. 2008;46(12):1813-21.

19. Johnson GL, Sarker SJ, Nannini F, et al. Aspergillus-specific lateral-flow device and real-time PCR testing of bronchoalveolar lavage fluid: a combination biomarker approach for clinical diagnosis of invasive pulmonary aspergillosis. J Clin Microbiol. 2015;53(7):2103-8.

20. White PL, Barnes RA, Springer J, et al. Clinical performance of Aspergillus PCR for testing serum and plasma: a study by the European Aspergillus PCR Initiative. J Clin Microbiol. 2015;53(9):2832-7.

21. White PL, Wingard JR, Bretagne S, et al. Aspergillus polymerase chain reaction: systematic review of evidence for clinical use in comparison with antigen testing. Clin Infect Dis. 2015;61(8):1293-303.

22. Maertens JA, Raad II, Marr KA, et al. Isavuconazole versus voriconazole for primary treatment of invasive mould disease caused by Aspergillus and other filamentous fungi (SECURE): a phase 3, randomised-controlled, non-inferiority trial. Lancet. 2016;387(10020):760-9.

23. Nucci F, Nouer SA, Capone D, Anaissie E, Nucci M. Fusariosis. Semin Respir Crit Care Med. 2015;36(5):706-14.

24. Marty FM, Ostrosky-Zeichner L, Cornely OA, et al. Isavuconazole treatment for mucormycosis: a single-arm open-label trial and casecontrol analysis. Lancet Infect Dis. 2016;16(7):828-37.

25. Cordonnier C, Cesaro S, Maschmeyer G, et al. Pneumocystis jirovecii pneumonia: still a concern in patients with haematological malignancies and stem cell transplant recipients. J Antimicrob Chemother. 2016;71(9):2379-85.

26. Maertens J, Cesaro S, Maschmeyer G, et al. ECIL guidelines for preventing Pneumocystis jirovecii pneumonia in patients with haematological malignancies and stem cell transplant recipients. J Antimicrob Chemother. 2016;71(9):2397-404.

27. Alanio A, Hauser PM, Lagrou K, et al. ECIL guidelines for the diagnosis of Pneumocystis jirovecii pneumonia in patients with haematological malignancies and stem cell transplant recipients. J Antimicrob Chemother. 2016;71(9):2386-96.

28. Maschmeyer G, Helweg-Larsen J, Pagano L, et al. ECIL guidelines for treatment of Pneumocystis jirovecii pneumonia in nonHIV-infected haematology patients. J Antimicrob Chemother. 2016;71(9):2405-13.

29. Erard V, Wald A, Corey L, Leisenring WM, Boeckh M. Use of long-term suppressive acyclovir after hematopoietic stem-cell transplantation: impact on herpes simplex virus (HSV) disease and drug-resistant HSV disease. J Infect Dis. 2007;196(2):266-70.

30. Ljungman P, Boeckh M, Hirsch HH, et al. Definitions of cytomegalovirus infection and disease in transplant patients for use in clinical trials. Clin Infect Dis. 2017;64(1):87-91.
31. Schmidt-Hieber M, Labopin M, Beelen D, et al. CMV serostatus still has an important prognostic impact in de novo acute leukemia patients after allogeneic stem cell transplantation: a report from the Acute Leukemia Working Party of EBMT. Blood. 2013;122(19):3359-64.

32. Green ML, Leisenring W, Xie H, et al. Cytomegalovirus viral load and mortality after haemopoietic stem cell transplantation in the era of pre-emptive therapy: a retrospective cohort study. Lancet Haematol. 2016;3(3):e119-27.

33. Boeckh M, Ljungman P. How we treat cytomegalovirus in hematopoietic cell transplant recipients. Blood. 2009;113(23):5711-9.

34. Boeckh M, Stevens-Ayers T, Travi G, et al. Cytomegalovirus (CMV) DNA quantitation in bronchoalveolar lavage fluid from hematopoietic stem cell transplant recipients with CMV pneumonia. J Infect Dis. 2017;215(10):1514-22.

35. Marty FM, Ljungman P, Chemaly RF, et al. Letermovir prophylaxis for cytomegalovirus in hematopoietic-cell transplantation. N Engl J Med. 2017;377(25):2433-44.

36. Boeckh M, Kim HW, Flowers ME, Meyers JD, Bowden RA. Longterm acyclovir for prevention of varicella zoster virus disease after allogeneic hematopoietic cell transplantation - a randomized double-blind placebo-controlled study. Blood. 2006;107(5):1800-5.

37. Styczynski J, van der Velden W, Fox CP, et al. Management of Epstein-Barr Virus infections and post-transplant lymphoproliferative disorders in patients after allogeneic hematopoietic stem cell transplantation: Sixth European Conference on Infections in Leukemia (ECIL-6) guidelines. Haematologica. 2016;101(7):803-11.

38. Zerr DM, Boeckh M, Delaney C, et al. HHV-6 reactivation and associated sequelae after hematopoietic cell transplantation. Biol Blood Marrow Transplant J Am Soc Blood Marrow Transplant. 2012;18(11):1700-8.

39. Kim YJ, Guthrie KA, Waghmare A, et al. Respiratory syncytial virus in hematopoietic cell transplant recipients: factors determining progression to lower respiratory tract disease. J Infect Dis. 2014;209(8):1195-204.

40. Chu HY, Englund JA, Podczervinski S, et al. Nosocomial transmission of respiratory syncytial virus in an outpatient cancer center. Biol Blood Marrow Transplant. 2014;20(6):844-51.

41. Seo S, Martin E, Xie H, et al. Human rhinovirus RNA detection in the lower respiratory tract of hematopoietic cell transplant recipients: association with mortality. Biol Blood Marrow Transpl. 2013;19(2 Supplement):S167-S8.

42. Ljungman P, de la Camara R, Perez-Bercoff L, et al. Outcome of pandemic H1N1 infections in hematopoietic stem cell transplant recipients. Haematologica. 2011;96(8):1231-5.

43. Mallet V, van Bommel F, Doerig C, et al. Management of viral hepatitis in patients with haematological malignancy and in patients undergoing haemopoietic stem cell transplantation: recommendations of the 5th European Conference on Infections in Leukaemia (ECIL-5). Lancet Infect Dis. 2016;16(5):606-17.

44. Cesaro S, Dalianis T, Hanssen Rinaldo C, et al. ECIL guidelines for the prevention, diagnosis and treatment of BK polyomavirus-associated haemorrhagic cystitis in haematopoietic stem cell transplant recipients. J Antimicrob Chemother. 2018;73(1):12-21. 